\title{
Metabolites from the Xylariaceous Fungus PSU-A80
}

\author{
Vatcharin Rukachaisirikul, ${ }^{*}, a$ Ubonta Sommart, ${ }^{a}$ Souwalak PhongPaichit, ${ }^{b}$ \\ Nongporn HutadiloK-Towatana, ${ }^{c}$ Nattawut RunguIndamai, ${ }^{d}$ and Jariya SAKayaroj ${ }^{d}$ \\ ${ }^{a}$ Department of Chemistry, Faculty of Science, Prince of Songkla University; ${ }^{b}$ Department of Microbiology, Faculty of \\ Science, Prince of Songkla University; ' Department of Biochemistry, Faculty of Science, Prince of Songkla University; \\ Hat Yai, Songkhla 90112, Thailand: and ${ }^{d}$ National Center for Genetic Engineering and Biotechnology (BIOTEC); \\ Thailand Science Park, Klong Luang, Pathumthani 12120, Thailand. Received April 19, 2007; accepted June 7, 2007
}

\begin{abstract}
One hypoxylonol, xylarenol (1), one hexadienoic acid, xylarenoic acid (2), and one tetralone, xylarenone (3), were isolated from the xylariaceous fungus PSU-A80 together with ten known compounds. The structures were established by analysis of spectroscopic data. 8-Methoxy-1-naphthol, one of the known metabolites, displayed good radical scavenging potency with an $\mathrm{IC}_{50}$ value of $30 \mu \mathrm{g} / \mathrm{ml}$.
\end{abstract}

Key words Xyraliacea; hypoxylonol; hexadienoic acid; tetralone; antioxidant activity

The family xylariaceae is a rich source of antimicrobial and/or antioxidant secondary metabolites, for example, carneic acids $\mathrm{A}-\mathrm{B},{ }^{1)}$ cohaerins $\mathrm{C}-\mathrm{F}^{2)}$ daldinins $\mathrm{C}-\mathrm{F},{ }^{3)}$ ramulosin, ${ }^{4)}$ and sassafrins A-D., During our ongoing search for biologically active metabolites from the endophytic fungi, the broth extract of the xylariaceous fungus PSU-A80, isolated from the leaves of Garcinia atroviridis, showed the antioxidant activity in 1,1-diphenyl-2-picrylhydrazyl (DPPH) free radical assay. To search for antioxidant metabolites, the ethyl acetate extracts from the culture broth and cell of the xylariaceous fungus PSUA80 were subjected to various chromatographic separation. Three new compounds, one hypoxylonol, xylarenol (1), one hexadienoic acid, xylarenoic acid (2), and one tetralone, xylarenone (3), were isolated together with ten known compounds, hypoxylonol B (4), ${ }^{6}$ 8-methoxy-1-naphthol, ${ }^{7)}$ (-)-5-methylmellein ${ }^{8}{ }^{8}(-)$-6-hydroxymellein, ${ }^{9)}$ isosclerone (5) ${ }^{10)}$ tyrosol, ${ }^{11)} \quad(E, E)-4$-hydroxymethyl-4,6-octadien-2,3diol, ${ }^{12)}(E)$-3-benzylidenehexahydro-2-methylpyrrolo[1,2-a]pyrazine-1,4-dione, ${ }^{13)}(E)$-3-benzylidenehexahydropyrrolo[1,2-a]pyrazine-1,4-dione, ${ }^{14)}$ and trans-4-hydroxy-6-methyl3,4,5,6-tetrahydro- $2 H$-pyran-2-one. ${ }^{15}$ The antioxidation activity of all isolates was performed in DPPH assay. This is also the first report on the isolation of $(E)$-3-benzylidenehexahydropyrrolo[1,2-a]pyrazine-1,4-dione and its $N$ methyl derivative as natural products.

\section{Results and Discussion}

Xylarenol (1) with the molecular formula $\mathrm{C}_{20} \mathrm{H}_{16} \mathrm{O}_{5}$ from HR-EI-MS, ${ }^{1} \mathrm{H}$ - and ${ }^{13} \mathrm{C}$-NMR data was isolated as a yellow gum. The UV and IR spectra were almost identical to those of $4,{ }^{6}$ thus indicating that they possessed the same chromophore and functional groups. The ${ }^{1} \mathrm{H}-\mathrm{NMR}$ spectrum displayed two hydroxyls $(\delta 12.60,8.22)$, three aromatic protons of a 1,2,3-trisubstituted benzene $(\delta 7.53,7.36,6.92)$, two ortho-coupled aromatic protons of a 1,2,3,4-tetrasubstituted

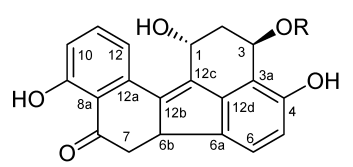

1: $\mathrm{R}=\mathrm{H}$

4: $\mathrm{R}=\mathrm{Me}$

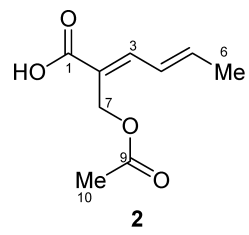

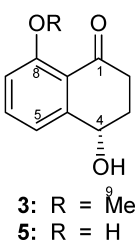

benzene $(\delta 7.24,6.77)$, two oxymethine protons $(\delta 5.67$, $5.28)$, one methine proton $(\delta 4.05)$ and two sets of nonequivalent methylene protons $(\delta 3.39,2.39$ and $\delta 2.80,2.02)$. These data were very similar to those of $\mathbf{4}$ except for the disappearance of a methoxyl signal in $\mathbf{1}$, suggesting the replacement of the methoxyl group in $\mathbf{4}$ with a hydroxyl group in $\mathbf{1}$. These results are in agreement with the molecular formula which indicated $\mathrm{CH}_{2}$ less than 4. Irradiation of $\mathrm{H}-3$ ( $\delta 5.28$, $\mathrm{dd}, J=10.0,4.5 \mathrm{~Hz}$ ) in the NOEDIFF experiment affected the intensity of $\mathrm{H}_{\mathrm{a}}-2(\delta 2.80, \mathrm{dt}, J=12.5,4.5 \mathrm{~Hz})$ and $4-\mathrm{OH}(\delta$ $8.22, \mathrm{~s})$ signals, but did not enhance the $\mathrm{H}-1$ ( $\delta 5.67$, t, $J=4.5 \mathrm{~Hz}$ ) signal, indicating trans relationship between $\mathrm{H}-1$ and $\mathrm{H}-3$. Since $\mathrm{H}-1$ was coupled with $\mathrm{H}_{\mathrm{ab}}-2$ with a small coupling constant of $4.5 \mathrm{~Hz}$, it was located at $\beta$-equatorial position. These results established the location of $\mathrm{H}-3$ at $\alpha$-axial. This assignment was supported by small and large coupling constants $(J=4.5,10.0 \mathrm{~Hz})$ between $\mathrm{H}_{\mathrm{ab}}-2$ and $\mathrm{H}-3$. H-6b appeared as a doublet of doublet at $\delta 4.05$ with $J$ values of 14.5 and $5.5 \mathrm{~Hz}$. Accordingly, it was placed at axial position. However, the NOEDIFF results could not determine the relative configuration of H-6b. Consequently, xylarenol (1) was identified as a new hypoxylonol derivative.

Xylarenoic acid (2) with the molecular formula $\mathrm{C}_{9} \mathrm{H}_{12} \mathrm{O}_{4}$ from HR-EI-MS was isolated as a colorless gum. The IR spectrum showed hydroxyl $\left(3373 \mathrm{~cm}^{-1}\right)$ and two carbonyl $\left(1720,1689 \mathrm{~cm}^{-1}\right)$ absorption bands. The ${ }^{1} \mathrm{H}-\mathrm{NMR}$ spectrum contained signals of trans-1,3-pentadienyl unit $[\delta 7.47(1 \mathrm{H}$, d, $J=11.5 \mathrm{~Hz}), 6.54(1 \mathrm{H}, \mathrm{ddq}, J=15.0,11.5,1.5 \mathrm{~Hz}), 6.32$ $(1 \mathrm{H}, \mathrm{dq}, J=15.0,6.9 \mathrm{~Hz})$ and $1.94(\mathrm{dd}, J=6.9,1.5 \mathrm{~Hz})]$, one oxymethylene group $(\delta 4.92, \mathrm{~s})$ and one methyl group ( $\delta$ $2.07,3 \mathrm{H}, \mathrm{s})$. The ${ }^{13} \mathrm{C}-\mathrm{NMR}$ spectrum showed two carbonyl carbons $(\delta 170.5,169.5)$, one quaternary carbon $(\delta 121.0)$, three olefinic methine carbons $(\delta 145.5,142.4,125.6)$, one oxymethylene carbon $(\delta 56.9)$ and two methyl carbons $(\delta$ $19.9,18.1) .{ }^{3} J$ HMBC correlations of H-3 $(\delta 7.47) / \mathrm{C}-1(\delta$ $169.5)$ and $\mathrm{C}-7$ ( $\delta$ 56.9) constructed a 2,4-hexadienoic acid skeleton bearing the oxymethylene group at $\mathrm{C}-2$. The remaining methyl group $(\delta 2.07)$ was connected with the ester carbonyl carbon $(\delta$ 170.5) which gave a HMBC correlation with $\mathrm{H}_{2}-7$ ( $\left.\delta 4.92\right)$. These results established the substituent at C-7 to be an acetoxyl group. Irradiation of H-4 ( $\delta 6.54)$, in the NOEDIFF experiment, enhanced signal intensity of $\mathrm{H}_{2}-7$ and $\mathrm{H}_{3}-6$, indicating that both double bonds had $E$ configura- 
tion. Thus, xylarenoic acid (2) was identified as a new 2,4hexadienoic acid.

Xylarenone (3) was obtained as a colorless gum with the molecular formula $\mathrm{C}_{11} \mathrm{H}_{12} \mathrm{O}_{3}$ from HR-EI-MS. The UV and IR spectra were almost identical to those of 5 . The ${ }^{1} \mathrm{H}-\mathrm{NMR}$ spectral data were very similar to those of $\mathbf{5}$ except that a hydroxyl signal at $\delta 12.43$ (s) in $\mathbf{5}$ was replaced, in $\mathbf{3}$, by a methoxyl signal at $\delta 3.86(\mathrm{~s})$. A HMBC correlation of the methoxy protons with C-8 $(\delta 160.1)$ and signal enhancement of these protons after irradiation of $\mathrm{H}-7$ ( $\delta 6.91, \mathrm{~d}$, $J=9.0 \mathrm{~Hz}$ ) in the NOEDIFF experiment supported the assignment. The configuration of C-4 was assigned as $S$, identical to that of $5([\alpha]+19),{ }^{16)}$ on the basis of their similar optical rotation. Therefore, xylarenone (3) was identified as a methyl ether of $\mathbf{5}$.

The crude ethyl acetate extracts of the broth and mycelia showed weak antioxidant activity using DPPH assay with $\mathrm{IC}_{50}$ values of 0.20 and $1.37 \mathrm{mg} / \mathrm{ml}$, respectively. At the concentration of $50 \mu \mathrm{g} / \mathrm{ml}$, compounds $\mathbf{1}, \mathbf{3}, 4$ and 8-methoxy-1naphthol were able to trap the DPPH radical with \% scavenging of $0.88,2.65,1.74$ and 63.50 , respectively. The remaining compounds showed no activity. 8-Methoxy-1-naphthol, the most potent antioxidant, gave the $\mathrm{IC}_{50}$ value of $30 \mu \mathrm{g} / \mathrm{ml}$ while the standard 2,6-di-tert-butyl-4-hydroxytoluene gave the $\mathrm{IC}_{50}$ value of $20 \mu \mathrm{g} / \mathrm{ml}$. It is worth to note that 1 , the demethylated derivative of $\mathbf{4}$, was less active than $\mathbf{4}$ whereas $\mathbf{3}$, the methylated derivative of $\mathbf{5}$, displayed better activity than 5.

A molecular identification of the xylariaceous fungus PSU-A80 was performed based on ITS sequence analysis because it did not produce conidia or spores. Its sequence matched with seven fungal sequences in the Family Xylariaceae, Annulohypoxylon stygium (DQ223761), A. stygium (DQ223760), Hypoxylon stygium (AJ390409), H. atroroseum (AJ390397), H. atroroseum (AF201712), A. atrororeum (DQ223734), and A. atroroseum (DQ223733) but with low bootstrap values (57\%). It showed only $67 \%$ homology to $A$. stygium (DQ223761) and A. stygium (DQ223760). Since there are not yet significant molecular data in GenBank for meaningful comparisons to be made for this fungus, the isolate PSU-A80 was then assigned to be Xylariaceae species (GenBank accession number EF530147).

\section{Experimental}

General Procedures Infrared spectra (IR) were recorded neat on a Perkin Elmer 783 FTS165 FT-IR spectrometer. Ultraviolet (UV) absorption spectra were measured on a SHIMADZU UV-160A spectrophotometer. ${ }^{1} \mathrm{H}-$ and ${ }^{13} \mathrm{C}$-NMR spectra were recorded on a $300 \mathrm{MHz}$ or a $500 \mathrm{MHz}$ Bruker FTNMR Ultra Shield ${ }^{\mathrm{TM}}$ spectrometer in $\mathrm{CDCl}_{3}$. Mass spectra were obtained on a MAT 95 XL Mass Spectrometer (Thermofinnigan). Optical rotations were measured in $\mathrm{MeOH}$ on a JASCO P-1020 polarimeter. Thin-layer chromatography (TLC) and precoated TLC were performed on silica gel $\mathrm{GF}_{254}$ (Merck). Column chromatography (CC) was carried out on Sephadex LH-20 or silica gel (Merck) type 100 (70-230 Mesh ASTM).

Fungal Material The xylariaceous fungus PSU-A80 was isolated from the leaves of Garcinia atroviridis, collected in Songkhla Province, Thailand in 2005. This fungus was deposited as PSU-A80 at the Department of Microbiology, Faculty of Science, Prince of Songkla University.

Identification of the Xylariaceous Fungus PSU-A80 The fungus PSUA 80 was identified based on the analysis of the DNA sequences of the ITS15.8S-ITS2, ITS regions of their ribosomal RNA gene. Genomic DNA was extracted from fungal mycelia grown with PDA using CTAB (cetyl trimethy ammonium bromide) method. ${ }^{17)}$ Primers ITS1 (TTTCCGTAGGTGAACCTG), ITS5 (GGAAGTAAAAGTCGTAACAAGG), and ITS4 (TCCTCCGCTTATTGATATGC) were used to amplify the ITS regions from the
DNA extract. The PCR reaction was performed using a DNA Engine DYAD ALD 1244 thermocycler (MJ Research, Inc.) with the following cycles: (1) $94{ }^{\circ} \mathrm{C}$ for $2 \mathrm{~min}$; (2) 35 cycles of $94^{\circ} \mathrm{C}$ for $1 \mathrm{~min}, 55^{\circ} \mathrm{C}$ for $1 \mathrm{~min}, 72^{\circ} \mathrm{C}$ for $2 \mathrm{~min}$, and (3) $72^{\circ} \mathrm{C}$ for $10 \mathrm{~min} .{ }^{18)}$ The amplified DNA fragment was purified with NucleoSpin ${ }^{\circledR}$ Extract DNA purification kit Cat. No. 740609.50 (Macherey-Nagel) and was sequenced by Macrogen Inc. using the same primers as for amplification. A BLAST search was used to search for closest matched sequences in the GenBank database. ${ }^{19)}$ Our fungal sequences and other related sequences were multiple aligned using BioEdit 7.0.5 $5^{20)}$ and the alignments were adjusted manually where necessary to maximize alignment. Phylogenetic relationships were estimated using PAUP* v4.0b10.21)

Fermentation and Isolation The xylariaceous fungus PSU-A80 was grown on potato dextrose agar (PDA) at $25^{\circ} \mathrm{C}$ for $5 \mathrm{~d}$. Three pieces $\left(0.5 \times 0.5 \mathrm{~cm}^{2}\right)$ of mycelial agar plugs were inoculated into $500 \mathrm{ml}$ Erlenmeyer flasks containing $300 \mathrm{ml}$ potato dextrose broth (PDB) at room temperature for 4 weeks. The culture (101) was filtered to give the filtrate and mycelia. The filtrate was extracted three times with EtOAc to afford a broth extract $(1.0 \mathrm{~g})$ as a brown gum. The crude EtOAc extract was separated by $\mathrm{CC}$ over Sephadex LH-20 using $50 \% \mathrm{MeOH}$ in $\mathrm{CH}_{2} \mathrm{Cl}_{2}$ to yield four fractions (A-D). Fraction B $(581.8 \mathrm{mg})$ was further purified by silica gel $\mathrm{CC}$ using a gradient of $\mathrm{MeOH}-\mathrm{CH}_{2} \mathrm{Cl}_{2}$ to give three fractions. The second fraction $\left(358.3 \mathrm{mg}\right.$, eluted with $1 \% \mathrm{MeOH}$ in $\mathrm{CH}_{2} \mathrm{Cl}_{2}$ ) upon purification on silica gel $\mathrm{CC}$ using a gradient system of $\mathrm{CH}_{2} \mathrm{Cl}_{2}$-light petroleum followed by that of $\mathrm{MeOH}-\mathrm{CH}_{2} \mathrm{Cl}_{2}$ gave eight subfractions. The first and the third subfractions contained 8-methoxy-1-naphthol $(15.9 \mathrm{mg})$ and $(-)-5$-methylmellein $(5.1 \mathrm{mg})$, respectively. Purification of the fifth subfraction $(34.8 \mathrm{mg}$, eluted with $60-90 \% \mathrm{CH}_{2} \mathrm{Cl}_{2}$ in light petroleum) on silica gel $\mathrm{CC}$ using $60 \%$ $\mathrm{CH}_{2} \mathrm{Cl}_{2}$ in light petroleum gave $5(5.2 \mathrm{mg})$. The sixth subfraction $(45.5 \mathrm{mg}$, eluted with $1 \% \mathrm{MeOH}$ in $\mathrm{CH}_{2} \mathrm{Cl}_{2}$ ) was subjected to silica gel $\mathrm{CC}$ using $20 \%$ EtOAc in light petroleum to afford $\mathbf{1}(1.5 \mathrm{mg}),(-)$-6-hydroxymellein $(1.3 \mathrm{mg}), \quad 4 \quad(1.8 \mathrm{mg}), \quad(E)$-3-benzylidenehexahydro-2-methylpyrrolo[1,2a]pyrazine-1,4-dione $(2.8 \mathrm{mg})$ and $(E)$-3-benzylidenehexahydropyrrolo[1,2a]pyrazine-1,4-dione $(2.0 \mathrm{mg})$. The last subfraction contained $(E, E)$-4-hydroxymethyl-4,6-octadien-2,3-diol $(7.5 \mathrm{mg})$. Fraction C $(235.3 \mathrm{mg})$ was purified using the same method as fraction $\mathrm{B}$ to give three fractions. The second fraction contained $2(2.2 \mathrm{mg})$. Wet mycelia were extracted twice with $500 \mathrm{ml}$ of $\mathrm{MeOH}$. After concentration of the $\mathrm{MeOH}$ solution to $100 \mathrm{ml}, \mathrm{H}_{2} \mathrm{O}$ $(100 \mathrm{ml})$ was added and the mixture washed with hexane $(300 \mathrm{ml})$. The residue was extracted three times with EtOAc $(200 \mathrm{ml}$ each). The ethyl acetate layer was washed with $\mathrm{H}_{2} \mathrm{O}$, dried over $\mathrm{Na}_{2} \mathrm{SO}_{4}$, and concentrated under reduced pressure to obtain a brown gum $(1.0 \mathrm{~g})$. The crude mycelial extract was fractionated on Sephadex LH-20 CC using $\mathrm{MeOH}$ to yield 3 fractions. The second fraction $(750.0 \mathrm{mg})$ was purified using the same method as fraction B to afford tyrosol $(3 \mathrm{mg}), 3(1.8 \mathrm{mg})$ and trans-4hydroxy-6-methyl-3,4,5,6-tetrahydro-2H-pyran-2-one (19.3 mg).

Xylarenol (1): Yellow gum, ${ }^{1} \mathrm{H}-\mathrm{NMR}(500 \mathrm{MHz}) \delta: 12.60(1 \mathrm{H}, \mathrm{s}, 9-\mathrm{OH})$, $8.22(1 \mathrm{H}, \mathrm{s}, 4-\mathrm{OH}), 7.53(1 \mathrm{H}, \mathrm{dd}, J=8.5,7.5 \mathrm{~Hz}, \mathrm{H}-11), 7.36(1 \mathrm{H}, \mathrm{dd}$, $J=7.5,0.5 \mathrm{~Hz}, \mathrm{H}-12), 7.24(1 \mathrm{H}, \mathrm{d}, J=8.0 \mathrm{~Hz}, \mathrm{H}-6), 6.92(1 \mathrm{H}, \mathrm{dd}, J=8.5$, $0.5 \mathrm{~Hz}, \mathrm{H}-10), 6.77(1 \mathrm{H}, \mathrm{d}, J=8.0 \mathrm{~Hz}, \mathrm{H}-5), 5.67(1 \mathrm{H}, \mathrm{t}, J=4.5 \mathrm{~Hz}, \mathrm{H}-1)$, $5.28(1 \mathrm{H}, \mathrm{dd}, J=10.0,4.5 \mathrm{~Hz}, \mathrm{H}-3), 4.05(1 \mathrm{H}, \mathrm{dd}, J=14.5,5.5 \mathrm{~Hz}, \mathrm{H}-6 \mathrm{~b})$, $3.39\left(1 \mathrm{H}, \mathrm{dd}, J=16.5,5.5 \mathrm{~Hz}, \mathrm{H}_{\mathrm{a}}-7\right), 2.80\left(1 \mathrm{H}, \mathrm{dt}, J=12.5,4.5 \mathrm{~Hz}, \mathrm{H}_{\mathrm{a}}-2\right)$, $2.39\left(1 \mathrm{H}, \mathrm{dd}, J=16.5,14.5 \mathrm{~Hz}, \mathrm{H}_{\mathrm{b}}-7\right), 2.02\left(1 \mathrm{H}, \mathrm{m}, \mathrm{H}_{\mathrm{b}}-2\right) .{ }^{13} \mathrm{C}-\mathrm{NMR}$ (125 MHz) $\delta: 204.2$ (s, C-8), 163.5 (s, C-9), 155.1 (s, C-4), 137.5 (s, C-12b), 137.0 (d, C-11), 135.9 (s, C-12c), 135.4 (s, C-6a, C-12a), 142.4 (s, C-12d), 123.2 (d, C-6), 117.7 (d, C-10), 117.3 (s, C-3a), 116.3 (d, C-12), 114.6 (d, C5), 114.6 (s, C-8a), 73.0 (d, C-3), 62.5 (d, C-1), 48.9 (d, C-6b), 42.8 (t, C-7), 36.3 (t, C-2). FT-IR (neat) $v_{\max } \mathrm{cm}^{-1}: 3774,1670 . \mathrm{UV} \lambda_{\max }(\mathrm{MeOH}) \mathrm{nm}$ ( $\log \varepsilon$ ): 223 (3.23), 251 (3.20), 265 (3.17), 289 (3.10), 389 (2.80). EI-MS $\mathrm{m} / \mathrm{z}$ (\% relative intensity): $318(100), 300(50), 290$ (28); HR-EI-MS $\mathrm{m} / \mathrm{z}$ $318.0890\left[\mathrm{M}-\mathrm{H}_{2} \mathrm{O}\right]^{+}\left(\right.$Calcd for $\left.\mathrm{C}_{20} \mathrm{H}_{14} \mathrm{O}_{4}: 318.0892\right)$. $[\alpha]_{\mathrm{D}}^{26}-70.4^{\circ}(c=$ $0.04, \mathrm{MeOH})$

Xylarenoic Acid (2): Colorless gum, ${ }^{1} \mathrm{H}-\mathrm{NMR}(300 \mathrm{MHz}) \delta: 7.47(1 \mathrm{H}, \mathrm{d}$, $J=11.5 \mathrm{~Hz}, \mathrm{H}-3), 6.54(1 \mathrm{H}, \mathrm{ddq}, J=15.0,11.5,1.5 \mathrm{~Hz}, \mathrm{H}-4), 6.32(1 \mathrm{H}, \mathrm{dq}$ $J=15.0,6.9 \mathrm{~Hz}, \mathrm{H}-5), 4.92(2 \mathrm{H}, \mathrm{s}, \mathrm{H}-7), 2.07(3 \mathrm{H}, \mathrm{s}, \mathrm{H}-10), 1.94(3 \mathrm{H}, \mathrm{dd}$ $J=6.9,1.5 \mathrm{~Hz}, \mathrm{H}-6) .{ }^{13} \mathrm{C}-\mathrm{NMR}(125 \mathrm{MHz}) \delta: 170.5(\mathrm{~s}, \mathrm{C}-9), 169.5(\mathrm{~s}, \mathrm{C}-1)$, 145.5 (d, C-3), 142.4 (d, C-5), 125.6 (d, C-4), 121.0 (s, C-2), 56.9 (t, C-7), 19.9 (q, C-10), 18.1 (q, C-6). FT-IR (neat) $v_{\text {c }} \mathrm{cm}^{-1}: 3373,1720,1689$. UV $\lambda_{\max }(\mathrm{MeOH}) \mathrm{nm}(\log \varepsilon): 257$ (1.84). EI-MS $m / z$ (\% relative intensity): 184 (5), 141 (12), 124 (100), 123 (30), 95 (35), 81 (42); HR-EI-MS m/z: 184.0740 [M] ${ }^{+}$(Calcd for $\mathrm{C}_{9} \mathrm{H}_{12} \mathrm{O}_{4}$ 184.0736).

Xylarenone (3): Colorless gum, ${ }^{1} \mathrm{H}-\mathrm{NMR}(300 \mathrm{MHz}) \delta$ : $7.46(1 \mathrm{H}, \mathrm{dd}$ $J=9.0,6.0 \mathrm{~Hz}, \mathrm{H}-6), 7.11(1 \mathrm{H}, \mathrm{d}, J=6.0 \mathrm{~Hz}, \mathrm{H}-5), 6.91(1 \mathrm{H}, \mathrm{d}, J=9.0 \mathrm{~Hz}, \mathrm{H}-$ 7), $4.83(1 \mathrm{H}, \mathrm{dd}, J=9.0,6.0 \mathrm{~Hz}, \mathrm{H}-4), 3.86(3 \mathrm{H}, \mathrm{s}, \mathrm{H}-9), 2.85(1 \mathrm{H}, \mathrm{ddd}$ $\left.J=18.0,9.0,3.0 \mathrm{~Hz}, \mathrm{H}_{\mathrm{a}}-2\right), 2.52\left(1 \mathrm{H}\right.$, ddd, $\left.J=18.0,9.0,3.0 \mathrm{~Hz}, \mathrm{H}_{\mathrm{b}}-2\right), 2.25$ 
$\left(1 \mathrm{H}, \mathrm{m}, \mathrm{H}_{\mathrm{a}}-3\right), 2.10\left(1 \mathrm{H}, \mathrm{m}, \mathrm{H}_{\mathrm{b}}-3\right) .{ }^{13} \mathrm{C}-\mathrm{NMR}(75 \mathrm{MHz}) \delta: 197.0(\mathrm{~s}, \mathrm{C}-1)$ 160.1 (s, C-8), 120.1 (s, C-8a), 147.8 (s, C-4a), 134.7 (d, C-6), 118.8 (d, C5), 112.0 (d, C-7), 68.5 (d, C-4), 56.1 (q, C-9), 36.3 (t, C-2), 31.3 (t, C-3) FT-IR (neat) $v_{\max } \mathrm{cm}^{-1}: 3419,1663$. UV $\lambda_{\max }(\mathrm{MeOH}) \mathrm{nm}(\log \varepsilon): 214$ (3.99), 254 (3.64), 317 (3.34). EI-MS $m / z$ (\% relative intensity): 192 (100), 164 (61), 135 (31), 136 (23); HR-EI-MS m/z: $192.0778[\mathrm{M}]^{+}$(Calcd for $\mathrm{C}_{11} \mathrm{H}_{12} \mathrm{O}_{3}$ 192.0786). $[\alpha]_{\mathrm{D}}^{28}+21.3^{\circ}\left(c=0.03, \mathrm{CHCl}_{3}\right)$.

Free Radical Scavenging Activity This was carried out according to that of Yen and Hsieh. ${ }^{22)}$ To different concentrations of a sample in methanol $(0.5 \mathrm{ml}$ each) was added $1 \mathrm{ml}$ of a methanolic solution of $0.2 \mathrm{~mm} \mathrm{DPPH}$. After mixing thoroughly, the mixture was allowed to stand in the dark for $30 \mathrm{~min}$ and the absorbance at $523 \mathrm{~nm}$ was measured using methanol for the baseline correction. The results were then compared with that of the control prepared as above but without any sample. Radical scavenging activity was expressed as percentage and was calculated using the following formula: \%scavenging $=\left[\left(\mathrm{A}_{\text {control }}-\mathrm{A}_{\text {sample }}\right) / \mathrm{A}_{\text {control }}\right] \times 100$. For 8-methoxy-1-naphthol, the result was also presented as $\mathrm{IC}_{50}$ (sample concentration that produced $50 \%$ scavenging of DDPH radical)

Acknowledgments U.S. thanks the Center for Innovation in Chemistry: Postgraduate Education and Research Program in Chemistry for a scholarship. The Graduate School, Prince of Songkla University, is gratefully acknowledged for partial support. Finally, S.P. thanks the Bioresources Research Network (BRN) for a research grant.

\section{References and Notes}

1) Quang D. N., Stadler M., Fournier J., Asakawa Y., J. Nat. Prod., 69, 1198-1202 (2006).

2) Quang D. N., Stadler M., Fournier J., Tomita A., Hashimoto T., Tetrahedron, 62, 6349-6354 (2006).

3) Quang D. N., Hashimoto T., Tanaka M., Stadler M., Asakawa Y., Phytochemistry, 65, 469-473 (2004).

4) Anderson J. R., Edwards R. L., Whalley A. J. S., J. Chem. Soc., Perkin Trans. 1, 9, 2185-2192 (1983).

5) Quang D. N., Hashimoto T., Fournier J., Stadler M., Radulovic N., Asakawa Y., Tetrahedron, 61, 1743-1748 (2005).
6) Koyama K., Kuramochi D., Kinoshita K., Takahashi K., J. Nat. Prod., 65, 1489-1490 (2002)

7) Thines E., Daussmann T., Semar M., Sterner O., Anke H., Z. Naturforsch. Sect. C, Biosci., 50, 813-819 (1995).

8) Cambie R. C., Lal A. R., Rutledge P. S., Woodgate P. D., Phytochemistry, 30, 287-292 (1991).

9) Ayer W. A., Attah-Poku S. K., Browne L. M., Orszanska H., Can. J. Chem., 65, 765-769 (1987).

10) Kokubun T., Veitch N. C., Bridge P. D., Simmonds M. S. J., Phytochemistry, 62, 779-782 (2003).

11) Capasso R., Cristinzio G., Evidente A., Scognamiglio F., Phytochemistry, 31, 4125-4128 (1992).

12) Fuchser J., Zeeck A., Liebigs Annalen/Recueil., 1, 87-95 (1997).

13) Jin S., Liebscher J., Synlett., 4, 459-461 (1999).

14) Jin S., Wessig P., Liebscher J., Eur. J. Org. Chem., 10, 1993-1999 (2000).

15) Buchanan M. S., Hashimoto T., Takaoka S., Kan Y., Asakawa Y., Phytochemistry, 42, 173-176 (1996).

16) Morita T., Aoki H., Agric. Biol. Chem., 38, 1501-1505 (1974).

17) O’Donnell K., Cigelnik E., Weber N. S., Trappe J. M., Mycologia, 89, 48 - 65 (1997).

18) White T. F., Bruns T., Lee S., Taylor J., "PCR Protocol: A Guide to Methods and Applications," ed. by Innis M. A., Gelfand D. H., Sninsky F. S., White T. T., Academic Press, San Diego, 1990, pp. 315322

19) Altschu S. F., Gish W., Miller W., Myers E. W., Lipman D. J., J. Mol. Biol., 215, 403-410 (1990).

20) Hall T., "Bioedit 7.0.5," Department of Microbiology, North Carolina State University, 2005. (Onlline) Available: http://www.mbio.ncsu.edu/ BioEdit/Bioedit.html [accessed 4 Febuary 2007].

21) Swofford D. L., "Phylogenetic Analysis Using Parsimony (and other methods) Version 54.0610," Sinauer Associates, Inc. Publishers, Sunderland, Massachusetts, 2002.

22) Yen G.-C., Hsieh G.-L., Biosci. Biotechnol. Biochem., 61, 1646-1649 (1997). 